\title{
Effect of Dietary Extruded Linseed and Walnut Meal Mixture (8:1) on Performance and Plasma Protein Profile in Weaned Piglets
}

\author{
Anca GHEORGHE ${ }^{1 *}$, Mihaela HĂBEANU ${ }^{1}$, Nicoleta Aurelia LEFTER $^{1}$, Daniela Mihaela GRIGORE ${ }^{1}$ \\ ${ }^{1}$ Department of Animal Nutrition, National Research-Development Institute for Animal Biology and \\ Nutrition, Calea Bucuresti no. 1, 077015, Balotesti, Romania. \\ *Corresponding author, e-mail: anca.gheorghe@ibna.ro
}

Bulletin UASVM Animal Science and Biotechnologies 75(2)/ 2018

Print ISSN 1843-5262; Electronic ISSN 1843-536X

DOI:10.15835/buasvmcn-asb: 2018.0019

\begin{abstract}
The effects of dietary extruded linseed (ELS):walnut meal (WM) mixture (8:1) on performance and plasma protein profile in weaned piglets was evaluated for $21 \mathrm{~d}$. Topigs piglets $(\mathrm{n}=40$; $B W=8.02 \pm 0.82 \mathrm{~kg})$, age $30 \pm 3$ days, were allotted into 2 groups and fed 2 diets: control [C, based on corn-triticale-soybean meal (SBM)] and experimental (ELS:WM, where the ELS:WM mixture (8:1) partially replace SBM). Blood samples were collected at $7 \mathrm{~d}$ and $21 \mathrm{~d}$ after weaning. The plasma protein profile (total protein, total bilirubin, albumin, creatinine, uric acid, urea nitrogen-BUN) were determined by a chemistry analyser. Dietary ELS:WM mixture improve the BW $(\mathrm{P}=0.047)$ and $\mathrm{ADG}(\mathrm{P}=0.036)$ of piglets at $21 \mathrm{~d}$ after weaning vs $\mathrm{C}$, whereas ADFI and $\mathrm{F}: \mathrm{G}$ ratio were increase $(\mathrm{P}>0.05)$. The plasma protein profile of piglets fed dietary mixture was not affected at $7 \mathrm{~d}$ and $21 \mathrm{~d}$ after weaning, except plasma BUN concentration that was decrease $(\mathrm{P}=0.027)$ at $21 \mathrm{~d}$ after weaning. Lower BUN concentration indicated higher availability of dietary nitrogen reflected in a higher deposition of protein. We concluded that dietary ELS:WM mixture improve piglets performance and positively afect plasma protein profile, especially BUN in weaning period.
\end{abstract}

Keywords: extruded linseed:walnut meal, performance, plasma parameters, weaned piglets

\section{INTRODUCTION}

In modern pig production, weaning is still associated with nutritional, environmental and immune challenges that may lead to considerable economic losses to pork producers (Li et al., 2014; Weng, 2017). Generally, weaning period is characterized by decreased feed intake, altered gut integrity and increased concentrations of inflammatory markers in blood (Le Dividich and Sève, 2000; Pié et al., 2004; Montagne et al., 2007).

The effects of dietary protein sources on growth and health of piglets have been studied extensively (Pluske et al., 2002; Kim et al., 2006; Wang et al., 2007; Hermes, 2011; Habeanu et al., 2015), but there is still a lack of information on the effect of dietary proteaginous sources (e.g. linseed, flaxseed, walnut by-products) or their mixture, rich sources of essential polyunsaturated fatty acids (PUFAs), which could help piglets to adapt to the rapidly changed diet during weaning (RodriguezLeyva et al., 2010; Li et al., 2014). Due to the rich content in alpha-linolenic acid (ALA) and lignans which have antimicrobial properties linseed is unique as a vegetable source (Kiarie et al., 2014). Walnut meal could be a valuable alternative to soybean meal, besides having a high protein level, is also a rich source of bioactive compounds (ALA, antioxidants, dietary fiber) with potential benefit on piglets health status. A mixture between linseed and walnut meal (8:1) could be a good opportunity 
Table 1. Ingredient and nutrient composition of piglets diets

\begin{tabular}{ccc}
\hline Ingredients, $\%$ & $\begin{array}{c}\text { Control } \\
\text { C }\end{array}$ & $\begin{array}{c}\text { Experimental } \\
\text { ELS:WM }\end{array}$ \\
\hline Corn & 44.11 & 40.93 \\
\hline Triticale & 25.00 & 25.00 \\
\hline Extruded linseed:walnut meal (8:1) & - & 9.00 \\
\hline Soybean meal & 18.00 & 13.00 \\
\hline Corn gluten & 3.00 & 3.00 \\
\hline Milk replacer & 5.00 & 5.00 \\
\hline Vegetable oil & 1.50 & 0.50 \\
\hline DL-Methionine & 0.04 & 0.11 \\
\hline L-Lysine & 0.34 & 0.52 \\
\hline Calcium carbonate & 1.70 & 1.72 \\
\hline Monocalcium phophate & 0.10 & 0.01 \\
\hline Phytase & 0.01 & 0.01 \\
\hline Salt & 0.10 & 0.10 \\
\hline Choline premix & 0.10 & 0.10 \\
\hline Vitamin-mineral premix ${ }^{1}$ & 1.00 & 1.00 \\
\hline Analysed composition, $\%$ & & 89.19 \\
\hline Dry matter & 89.52 & 18.33 \\
\hline Crude protein & 18.75 & 1.20 \\
\hline Lysine & 1.20 & 0.72 \\
\hline Methionine+Cystine & 0.72 & 0.90 \\
\hline Calcium & 0.90 & 0.78 \\
\hline Phosphorus & 0.78 & 4.73 \\
\hline Crude fiber & 4.75 & 3.30 \\
\hline Crude fat & 3.69 & \\
\hline Metabolisable energy ME $(\mathrm{kcal} / \mathrm{kg})^{2}$ & 3260.7 & 256.9 \\
\hline
\end{tabular}

Note: ${ }^{1}$ Vitamin mineral premix added at $1 \%$ to the diet contained (per kg feed): 10000 IU vitamin A; 2000 IU vitamin D3; 30 IU vitamin E; 3 mg vitamin K3; 2 mg vitamin B1; 6 mg vitamin B2; 20 mg vitamin B3; 13.5 mg vitamin B5; 3 mg vitamin B6; 0.06 mg vitamin B7; $0.8 \mathrm{mg}$ vitamin B9; $0.05 \mathrm{mg}$ vitamin B12; $10 \mathrm{mg}$ vitamin C; $30 \mathrm{mg}$ of Mn; $110 \mathrm{mg}$ of Fe; $25 \mathrm{mg} \mathrm{Cu} ; 100 \mathrm{mg} \mathrm{Zn;} 0.38 \mathrm{mg} \mathrm{I} ; 0.36 \mathrm{mg} \mathrm{Se;} 0.3$ mg Co; $60 \mathrm{mg}$ antioxidant. ${ }^{2} \mathrm{ME}$ calculated based of feed ingredients composition using regression equations (NRC, 1998).

to improve the energy, amino acids and the fatty acid content of the compound feed.

The complementary effect of dietary proteaginous mixture on plasma protein profile in piglets is still little known, therefore this study was conducted to evaluate the effects of dietary extruded linseed: walnut meal mixture $(8: 1)$ on growth performance and plasma protein profile in weaned piglets for $21 \mathrm{~d}$.

\section{MATERIAL AND METHODS}

The animals were treated in accordance with EU Directive 2010/63/EU (OJEU, 2010) and all experimental procedure was approved by the
Animal Care Committee of the National ResearchDevelopment Institute for Animal Biology and Nutrition (Balotesti, Romania).

Animals and experimental design. Forty weaned piglets Topigs [ $\$$ Large White $\mathrm{x}$ Hybride

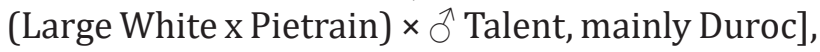
average body weight (BW) $8.02 \pm 0.82 \mathrm{~kg}$, age $30 \pm 3$ days, were randomly divided into 2 groups with 2 replicate each. Piglets were fed with 2 diets: control [C, based on corn-triticale-soybean meal (SBM)] and experimental (ELS:WM, where the mixture of extruded linseed:walnut meal (8:1) replaced $27.8 \%$ of SBM) for $21 \mathrm{~d}$. The diets (Tab. 1) were isocaloric and isoenergetic, formulated to meet 
Table 2. Chemical composition of feed ingredient and dietary mixture used in piglets diets

\begin{tabular}{cccc}
\hline Item, \% & Extruded linseed & Walnut meal & $\begin{array}{c}\text { Dietary mixture } \\
\text { ELS:WM (8:1) }\end{array}$ \\
\hline Dry matter & 91.09 & 90.91 & 91.00 \\
\hline Crude protein & 18.26 & 36.53 & 27.40 \\
\hline Crude fat & 21.18 & 7.42 & 14.30 \\
\hline Crude fiber & 17.04 & 14.07 & 15.56 \\
\hline ME, kcal $/ \mathrm{kg}^{1}$ & 3970 & 3174 & 3572 \\
\hline
\end{tabular}

Note: ${ }^{1} \mathrm{ME}$ calculated based of feed ingredients/dietary mixture composition using regression equations (NRC, 1998).

Table 3. Growth performance of piglets fed dietary ELS:WM mixture (8:1)

\begin{tabular}{ccccc}
\hline Item & $\begin{array}{c}\text { Control } \\
\text { diet }\end{array}$ & Experimental diet & SEM & P-value \\
\hline BW at weaning, kg & 7.93 & $8.07^{\mathrm{a}}$ & 0.14 & 0.662 \\
\hline BW at 21d after weaning, kg & $12.21^{\mathrm{b}}$ & $13.53^{\mathrm{a}}$ & 0.03 & 0.047 \\
\hline ADG, g & $0.214^{\mathrm{b}}$ & $0.235^{\mathrm{a}}$ & 0.005 & 0.036 \\
\hline ADFI, g & 0.370 & 0.420 & 0.08 & 0.130 \\
\hline F:G ratio, g feed:g gain & 1.73 & 1.79 & 0.07 & 0.128 \\
\hline
\end{tabular}

Note: BW, body weight; ADG, average daily gain; ADFI, average daily feed intake; SEM, standard error of the mean; Different letters between column denote significant differences (Tukey test, $\mathrm{p}<0.05$ ).

similar content of essential aminoacids (lysine and methionine), calcium and phosphorus, in accordance with nutrient requirements of hybrid (Topigs, 2012). The basal chemical composition of extruded linseed, walnut meal and the dietary mixture used in this study are presented in Tab. 2 . Feed and water were given ad libitum to piglets for all experimental period.

The growth performance parameters were evaluated: body weight (BW) at weaning and at 21d after weaning, feed intake (FI), from which average daily gain (ADG), average daily feed intake (ADFI) and feed conversion ratio (F:G ratio) were calculated.

Chemical and biochemical analyses. The chemical composition of feed ingredients and compound feeds samples were determined using standardized methods (OJEU, 2009).

Blood samples were collected from 8 piglets per group ( 4 male and 4 female) at $7 \mathrm{~d}$ and $21 \mathrm{~d}$ after weaning by jugular venipuncture in heparinized vacutainer tubes $(6 \mathrm{~mL})$. After blood samples were centrifuged (3000 rpm for $15 \mathrm{~min}$.) the plasma protein profile (total protein, T-Pro; total bilirubin, T-Bil; albumin, Alb; creatinine, Cre; uric acid, UA; urea nitrogen, BUN) were determined by a chemistry analyser (Spotchem EZ SP-4430, Arkray, Japan) using commercial kits.

Statistical analysis. The data obtained were analysed using the GLM procedure (SPSS, 2011). One-way analysis of variance (ANOVA) with the Tukey's comparison test was used to evaluate statistical significance of differences between dietary treatments. The results are expresed as means and standard error of the mean (SEM). Differences were considered significant at $\mathrm{P} \leq 0.05$. Replicate was considered as experimental unit in case of growth performance and each individual for plasma parameters determinations.

\section{RESULTS AND DISCUSSION}

Growth performance. Table 3 presents the average body weight, average daily gain, average daily feed intake and feed conversion ratio of piglets fed dietary extruded linseed:walnut meal mixture (8:1). Our results shown that piglets fed dietary mixture had higher BW $(+10.81 \%$; $\mathrm{P}=0.047)$ and $\mathrm{ADG}(+9.81 \% ; \mathrm{P}=0.036)$ at $21 \mathrm{~d}$ after 
Table 4. Plasma protein profile at $7 \mathrm{~d}$ and $21 \mathrm{~d}$ after weaning of piglets fed dietary ELS:WM mixture (8:1)

\begin{tabular}{|c|c|c|c|c|c|c|}
\hline Parameters & $\begin{array}{c}\text { References } \\
\text { value }^{*}\end{array}$ & Day & Control diet & $\begin{array}{c}\text { Experimental } \\
\text { diet }\end{array}$ & SEM & P-value \\
\hline \multirow{2}{*}{ T-Pro, g/dl } & \multirow[b]{2}{*}{ 5.8-8.3 } & 7 & 4.98 & 4.75 & 0.09 & 0.269 \\
\hline & & 21 & 5.4 & 5.18 & 0.11 & 0.379 \\
\hline \multirow{2}{*}{ Alb, g/dl } & \multirow[b]{2}{*}{$2.3-4.0$} & 7 & 2.75 & 2.76 & 0.06 & 0.927 \\
\hline & & 21 & 3.13 & 3.03 & 0.08 & 0.595 \\
\hline \multirow{2}{*}{ T-Bil, mg/dl } & \multirow[b]{2}{*}{$0-0.5$} & 7 & 0.25 & 0.30 & 0.02 & 0.275 \\
\hline & & 21 & 0.25 & 0.29 & 0.02 & 0.348 \\
\hline \multirow{2}{*}{ Cre, mg/dl } & \multirow[b]{2}{*}{$0.8-2.3$} & 7 & 1.40 & 1.30 & 0.04 & 0.188 \\
\hline & & 21 & 1.32 & 1.20 & 0.03 & 0.418 \\
\hline \multirow{2}{*}{$\mathrm{UA}, \mathrm{mg} / \mathrm{dl}$} & & 7 & 0.68 & 0.65 & 0.01 & 0.454 \\
\hline & & 21 & 0.63 & 0.62 & 0.02 & 1.00 \\
\hline \multirow{2}{*}{$\mathrm{BUN}, \mathrm{mg} / \mathrm{dl}$} & \multirow[b]{2}{*}{$8.2-25$} & 7 & 14.75 & 13.44 & 0.70 & 0.129 \\
\hline & & 21 & $13.98^{a}$ & $11.89^{b}$ & 0.60 & 0.027 \\
\hline
\end{tabular}

Note: *Merck Veterinary Manual (2010). Tenth Edition. Merck \&Co. Inc., USA; T-Pro, total protein; Alb, albumin; T-Bil, total bilirubin; Cre, creatinine; UA, uric acid; BUN, urea nitrogen; SEM, standard error of the mean. Different letters between column denote significant differences (Tukey test, $\mathrm{p}<0.05$ ).

weaning compared with $\mathrm{C}$, whereas ADFI and F:G ratio were insignificantly increase $(\mathrm{P}>0.05)$. The improvement in growth performance of piglets could be attributed to the anti-inflammatory properties of n-3 PUFA and bioactive compounds with benefits on health status contained by dietary extruded linseed:walnut meal mixture and confirmed that dietary mixture represent a viable alternative that could partially replace the soybean meal in piglet diets.

The effects of feeding linseed was extensively studied on grower-finisher pigs and had been stated that linseed is an effective feed for increasing the n-3 PUFA content of pig meat and improve the n-6:n-3 PUFA ratio (Rentfrow et al., 2003). Previous findings (Matthews et al., 2000; Riley et al., 2000; Kouba et al., 2003; Corino et al., 2008; Guillevic et al., 2009; Bečková and Václavková, 2010; Nurnberg et al., 2011) reported that inclusion of linseed in pig diets may improve the nutritional value of pork meat without deleteriously affecting organoleptic characteristics, oxidation or colour stability and enhance the levels of $n-3$ fatty acids, which have a potentially positive health effect in humans.

However, from our knowledge little scientific literature are available about the effect of feeding linseed or dietary extruded linseed mixture on performance of piglets for comparison. Quiniou et al. (2010) evaluated the effect of extruded lineseed incorporation in diets of sows' (3.5\%) and/or pigs' $(2 \%)$ on both performance of sows and their progeny. The authors stated that the addition of extruded linseed significantly faster the farrowing progress, the survival rate of piglets weighing between 1.0 and $1.4 \mathrm{~kg}$ at birth was significantly improved and pig's performance (daily feed intake, feed conversion ratio, or carcass fatness) from 24 to $110 \mathrm{~kg} \mathrm{BW}$ were significantly influenced by the treatment. Quiniou et al. (2010) observed during the growing phase a significant higher ADG in pigs fed extruded lineseed and suggested that more investigations would be required in order to determine whether this improved growth rate would result from a better adaptation capacity to new breeding conditions induced by the antiinflammatory properties of n-3 PUFA stored in pigs during gestation and lactation, or not.

Recently, Habeanu et al. (2017) reported that dietary peas:linseed mixture (3:1) did not significantly affect the growth performance, lipid and protein biochemical profile, and suggested that the combination of these valuable vegetable sources give the opportunity to optimize diet for weaning piglets.

Biochemical parameters. The effects of dietary mixture of extruded linseed:walnut meal 
on plasma protein profile of piglets at 7 and $21 \mathrm{~d}$ after weaning are given in Tab. 4. The growth performance of piglets are affected by the metabolic efficiency reflected by level of plasma parameters value that are considered important markers for health status (Habeanu et al., 2011; Yeom et al., 2012).

Our results shown that at $7 \mathrm{~d}$ after weaning plasma protein profile of piglets fed dietary mixture was not affected, the concentrations of T-Pro, Alb, T-Bil, Cre, UA and BUN were similar between treatments $(\mathrm{P}>0.05)$ and range in normal limits (Merck Veterinary Manual, 2010).

There were no difference in plasma protein profile at $21 \mathrm{~d}$ after weaning, except the plasma urea nitrogen (BUN) concentration that significantly decreased with $14.95 \%(\mathrm{P}=0.027)$ as result of feeding dietary mixture.

Plasma urea is considered an important marker of protein utilization efficiency (Heo et al., 2009; Kim et al., 2012). Lower concentration of BUN indicated higher availability of dietary nitrogen (Figueroa et al., 2002; Shen et al., 2012) reflected in a higher deposition of protein, which may explain the better performance response of piglets fed dietary mixture.

It is widely known that BUN and creatinine (a non-protein nitrogenous compound produced by the breakdown of creatine in muscle), are indicators of renal function, but creatinine (Cre) it is less influenced by other factors such as diet and hydration (Washington and Van Hoosier, 2012).

The concentrations of BUN and Cre obtained in our study were between normal values: 8.2$25 \mathrm{mg} / \mathrm{dl}$ for BUN and $0.8-2.3 \mathrm{mg} / \mathrm{dl}$ for Cre (Merck Veterinary Manual, 2010). According to Washington and Van Hoosier, (2012) a normal BUN:Cre ratio is $10-20 \mathrm{mg} / \mathrm{dl}$ to $1 \mathrm{mg} / \mathrm{dl}$, and an increased or decreased BUN:Cre ratio indicates renal disorder. Our results shown that the dietary treatments did not influence the BUN:Cre ratio at 7 and $21 \mathrm{~d}$ after weaning, the values obtained were in normal limits ( $>10 \mathrm{mg} / \mathrm{dl}$ ). Previously, Habeanu et al., (2017) noted that fed piglets with a peas: linseed (3:1) mixture had no significant effect on plasma protein profile and BUN:Cre ratio at $21 \mathrm{~d}$ after weaning.

\section{CONCLUSION}

Our results suggest that dietary extruded linseed: walnut meal mixture $(8: 1)$ improve growth performance and has a positive effect on biochemical parameters, especially on urea nitrogen of piglets in weaning period and could represent a good alternative that partially replace the soybean meal in piglets.

Acknowledgments. This work was financial supported by the Romanian Ministry of Research and Innovation [Nucleus Program, grant 1820 0103, 2018].

\section{REFERENCES}

1. Bečková R, Václavková E (2010). The effect of linseed diet on carcass value traits and fatty acid composition in muscle and fat tissue of fattening pigs. Czech Journal of Animal Science, 55: 313-320.

2. Corino C, Musella M, Mourot J (2008). Influence of extruded linseed on growth, carcass composition, and meat quality of slaughtered pigs at one hundred ten and one hundred sixty kilograms of live weight. Journal of Animal Science, 86: 1850-1860.

3. Figueroa JL, Lewis AJ, Miller PS, Fischer RL, Gomez RS, Diedrichsen RM (2002). Nitrogen metabolism and growth performance of gilts fed standard corn-soybean meal diets or low-crude protein, amino acid-supplemented diets. Journal of Animal Science, 80: 2911-2919.

4. Guillevic M, Kouba M, Mourot J (2009). Effect of a linseed diet or a sunflower diet on performances, fatty acid composition, lipogenic enzyme activities and stearoylCoAdesaturase activity in the pig. Livestock Science, 124: 288-294.

5. Habeanu M, Hebean V, Nagy Al, Taranu I, Lefter NA, Marin D, Grosu H (2011). The dietary omega-3 PUFA alter the metabolic and immunologic serum profile in Mangalitza pigs in rearing extensive system. Archiva Zootechnica, 14(1): 5-12.

6. Habeanu M, Lefter NA, Gheorghe A, Tabuc C, Untea AE, Surdu I, Balan CG (2015). Changes in certain serum and faeces parameters in weaned piglets as a response to nutritional stress. South African Journal of Animal Sciences, 45(2): 164-172.

7. Habeanu M, Lefter N, Gheorghe A, Tabuc C, Dumitru M, Ciurescu G, Palade M (2017). Effects of dietary peas mixed with linseed (3:1) on the growth performance, enteritis and certain serum parameter in weaned piglets. Food and Feed Research, 44 (2): 173-180.

8. Heo JM, Kim JC, Hansen CF, Mullan BP, Hampson DJ, Pluske JR (2009). Feeding a diet with decreased protein content reduces indices of protein fermentation and the incidence of postweaning diarrhea in weaned pigs challenged with an enterotoxigenic strain of Escherichia coli. Journal of Animal Science, 87: 2833-2843.

9. Hermes RG (2011). Natural feeding to reduce enteric disorder and improve adaptation of young pigs to weaning. PhD Thesis. Facultat de Veterinaria de Barcelona. http:// www.tesisenred.net.

10. Kiarie E, Nyachoty CM, Slominski BA, Blank G (2007). Growth performance, gastro-intestinal microbial activity 
and nutrient digestibility in early-weaned pigs fed diets containing flaxseed and carbohydrase enzyme. Journal of Animal Science, 85: 2982-2993.

11. Kim JC, Mullan BP, Frey B, Payne HG, Pluske JR (2012). Whole body protein deposition and plasma amino acid profiles in growing and/or finishing pigs fed increasing levels of sulphur amino acids with and without Escherichia coli lipopolysaccharide challenge. Journal of Animal Science 90, 362-365.

12. Kim YG, Lohakare JD, Chae BJ (2006). Growth performance, nutrient digestibility and intestinal morphology in weaned piglets fed fungal and bacterial fermented soya proteins. Journal of Animal and Feed Sciences, 15: 213-224.

13. Kouba M, Enser M, Whittington FM, Nute GR, Wood JD (2003). Effect of a high-linolenic acid diet on lipogenic enzyme activities, fatty acid composition, and meat quality in the growing pig. Journal of Animal Science, 81: 1967-1979.

14. Le Dividich J, Sève B (2000). Effects of underfeeding during the weaning period on growth, metabolism, and hormonal adjustments in the piglet. Domestic Animal Endocrinology, 19: 63-74.

15. Li Q, Brendemuhl JH, Jeong KC, Badinga L (2014). Effects of dietary omega-polyunsaturated fatty acids on growth and immune response of weanling pigs. Journal of Animal Science, 56: 1-7.

16. Matthews KR, Homer DB, Thies F, Calder PC (2000). Effect of whole linseed (Linum usitatissimum) in the diet of finishing pigs on growth performance and on the quality and fatty acid composition of various tissues. British Journal of Nutrition, 83: 637-643.

17. Montagne L, Boudry G, Favier $C$, Le Huërou-Luron I, Lallès JP, Sève B (2007). Main intestinal markers associated with the changes in gut architecture and function in piglets after weaning. British Journal of Nutrition, 97: 45-57.

18. Merck\&Co Inc. (2010). Merck Veterinary Manual (10th ed.), USA, (Chapter Reference Value).

19. Nurnberg K, Nurnberg G, Dannenberger D, Hagemann L, Paulke T (2011). Effect of extruded linseed on growth and lipids of muscle and back fat in pigs. Fleischwirtschaft, 91: 88-92.

20. NRC (1998). Nutrient Requirements of Swine. 10th rev. edn. National Academy Press, Washington, DC.

21. OJEU Official Journal of the European Union L 54 (2009). Commission Regulation (EC) No. 152/2009 laying down the methods of sampling and analysis for the official control of feed. Series L 155: 1-66.
22. OJEU Official Journal of the European Union (2010). Directive 2010/63/EU of the European Parliament and of the Council on the Protection of Animals Used for Scientific Purposes. Series L 276: 33-79.

23. Pié S, Lallès JP, Blazy F, Laffitte J, Sève B, Oswald IP (2004). Weaning is associated with an up-regulation of expression of inflammatory cytokines in the intestine of piglets. Journal of Nutrition, 134: 641-647.

24. Pluske JR, Pethick DW, Hopwood DE, Hampson DJ (2002). Nutritional influences on some major enteric bacterial diseases of pigs. Nutrition Research Reviews, 15: 333371.

25. Quiniou N, Goues T, Vautier A, Nassy G, Chesneau G, Weill P, Etienne M, Mourot J (2010). Consequence of extruded linseed incorporation in sows and/or pigs' diets on performance. Conference at the 61st Annual Meeting of the European Association for Animal Production, Heraklion, Crete Island, Greece, $5 \mathrm{pp}$.

26. Rentfrow G, Sauber T, Allee G, Berg EP (2003). The influence of diets containing either conventional corn with choice with grease, high oil corn, or high oil high oleic corn on belly/bacon quality. Meat Science, 64: 459-466.

27. Riley PA, Enser M, Nute GR, Wood JD (2000). Effects of dietary linseed on nutritional value and other quality aspects of pig muscle and adipose tissue. Animal Science, 71: 483-500.

28. Rodriguez-Leyva D, Mc Bassett C, Mc Cullough R, Pierce GN (2010). The cardiovascular effects of flaxseed and its omega-3 fatty acid, alphalinolenic acid. Canadian Journal of Cardiology, 26: 489-496.

29. SPSS (2011). Statistics version 20.0. IBM SPSS Inc, USA.

30. TOPIGS (2012). Feeding Manual Topigs Norsvin. TEMPO.

31. Yeom SC, Cho SY, Lee WJ (2012). Analysis of reference interval and age-related changes in serum biochemistry and hematology in the specific pathogen miniature pig. Laboratory Animal Research, 28(4): 245-253.

32. Wang NF, Chen Q, Le GW, Shi YH, Sun J (2007). Effect of lactic acid fermented soyabean meal on the growth performance, intestinal microflora and morphology of weaned piglets. Journal of Animal and Feed Sciences, 16: 75-85.

33. Washington IM, Van Hoosier G (2012). The laboratory rabbit, guinea pig, hamster, and other rodents. Clinical Biochemistry and Hematology. Doi: 10.1016/B978-0-12380920-9.00003-1.

34. Weng RC (2017). Dietary fat preference and effects on performance of piglets at weaning. Asian-Australasian Journal of Animal Science, 30(6): 834-842. 